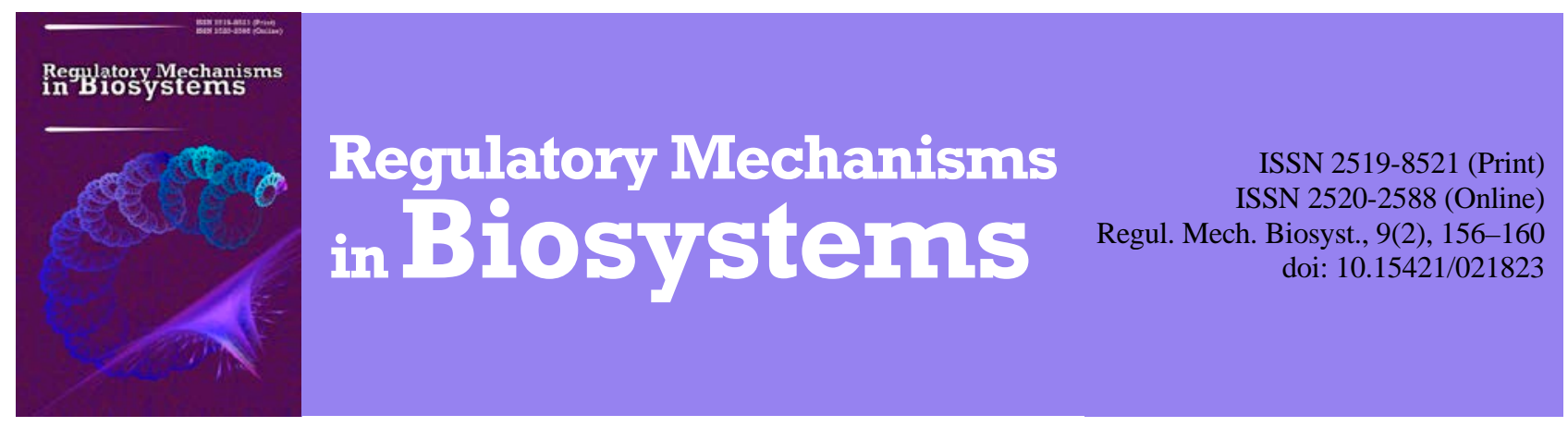

\title{
Effect of agrotechnological elements on milk thistle (Silynum marianum) productivity
}

\author{
R. A. Vozhehova*, M. I. Fedorchuk**, Y. O. Lavrynenko*, \\ S. V. Kokovikhin*, P. V. Lykhovyd*, I. M. Biliaieva*, V. V. Nesterchuk* \\ *Institute of Irrigated Agriculture, Kherson, Ukraine \\ **Mykolaiv National Agrarian University, Mykolaiv, Ukraine
}

Article info

Received 04.04.2018 Received in revised form
26.04.2018

Accepted 29.04.2018

Institute of Irrigated Agriculture, Kherson, Naddniprianske, 73483 , Ukraine.

Tel.: +38-066-062-98-97. E-mail:

pavel.likhovid@gmail.com

Mykolaiv National Agrarian University,

Heorhiya Honhadze st., 9, Mykolaiv, 54000, Ukraine.
Vozhehova, R. A., Fedorchuk, M. I., Lavrynenko, Y. O., Kokovikhin, S. V., Lykhovyd, P. V., Biliaieva, I. M., \& Nesterchuk, V. $V$. (2018). Effect of agrotechnological elements on milk thistle (Silynum marianum) productivity. Regulatory Mechanisms in Biosystems, 9(2), 156-160. doi:10.15421/021823

The milk thistle is a highly valuable medicinal plant, widely used in treatment of liver diseases. Soil-climate conditions of the steppe zone of Ukraine are favourable for crop cultivation. The goal of the study was to determine relations between milk thistle productivity and elements of cultivation technology, viz., primary tillage depth (14-16 and 20-22 cm), inter-row spacing (30, 45, $60 \mathrm{~cm}$ ), timing of sowing (3rd decade of March, middle of April, 3rd decade of April) and mineral fertilizer application doses (no fertilizers, $\mathrm{N}_{45} \mathrm{P}_{45}, \mathrm{~N}_{90} \mathrm{P}_{90}$ ). Field trials were carried out during the period from 2010 to 2012 on the irrigated lands of the Institute of Rice of the National Academy of Agrarian Sciences of Ukraine by using the split plot design method in four replications. The climate of the territory of the trials is typical for the steppe zone. The soil type was dark-chestnut residual solonetz middle-loamy soil. We used the Yuhoslava variety of milk thistle in the trials. Cultivation technology was standard, excluding the studied factors. The results of the trials showed significant impact of all the studied cultivation technology elements on milk thistle seed and oil yields. The maximum average seed (1.66 tha) and oil ( $489 \mathrm{~kg} / \mathrm{ha}$ ) yields were obtained under the primary tillage at the depth of 20-22 cm, inter-row spacing of $60 \mathrm{~cm}$, sowing in the 3rd decade of March, applying mineral fertilizers in a dose of $\mathrm{N}_{90} \mathrm{P}_{90}$. The highest input in seed and oil yields rise was made by the mineral fertilizers, which increased milk thistle productivity by 1.57 times comparatively with non-fertilized treatments. We also established a strong direct interrelationship between seed and oil yield: coefficient of determination was 0.96 . Results of the current study are slightly limited, so further investigations in the field of milk thistle cultivation technology development and improvement are required to provide Ukrainian farmers with scientifically grounded agrotechnology of this valuable medicinal plant.

Keywords: primary tillage depth; inter-row spacing; timing of sowing; mineral fertilizers dose; medicinal plant; seed yield; oil yield

\section{Introduction}

Medicinal plants have been widely used by humanity for treatment of various diseases since ancient times. The development of modern chemistry has moved them to the background, but no chemical drugs can replace the natural mild treatment provided by the medicinal plantbased drugs. Nowadays, interest in medicinal plants is growing. Questions dedicated to production of high-quality plant raw materials are of great relevance. At the moment, China and India are the leading countries in production of the medicinal plants, and the main consumers are Japan and the Republic of Korea. Germany is considered to be an important European center of trading and usage of medicinal plants (Lange, 2002). Ukraine has favourable soil-climate conditions for successful production of major medicinal plants, especially, on the South. Domestic cultivation of medicinal and aromatic plants provides great opportunities for export of the raw materials to developed countries of Europea and Asia and for native production of perfumes and plant-based drugs.

Among the medicinal plants a special place is occupied by the milk thistle (Silynum marianum L. Gaertn.). The milk thistle is a member of the Asteraceae family. It is considered that it originated in the Mediterranean Basin. The milk thistle grows as a wild weed in many European countries, North Africa, Southern and Northern America, Central and Western Asia, Southern Australia (Chiavari et al., 1991;
Morazzoni \& Bombardelli, 1995; Carrier et al., 2002). In Pakistan and Iran it is well-known as a troublesome weed in wheat crops (Khan et al., 2009; Shamsi, 2009). But on the other hand, the milk thistle is a highly valuable medicinal plant, well-known among health-care specialists from ancient times (Barnes et al., 2003; Ross, 2008). It is used in treatment of different liver and biliary diseases, mainly, because of the silymarin content in seeds (Flora et al., 1998; Siegel \& Stebbing, 2013; Saki et al., 2015). Some studies report the high efficiency of treatment with milk thistle medicine even in case of chronic liver diseases (Seeff et al., 2001). It is proved that it can prevent liver cancer (Tamayo \& Diamond, 2007) and has a lot of other advantages over many conventional drugs (Post-White et al., 2007). Scientific studies of the use of milk thistle use in medicine are still being carried out (Albassam et al., 2017), particularly, in the field of appropriation of the different crop cultivars for preparing drugs (Lucini et al., 2016). To supply medicine with high-quality raw material, cultivation technologies of the medicinal plants should be carefully studied. And milk thistle is no exception. Lack of scientifically grounded information on the cultivation technologies of medicinal plants is one of the main obstacles in their production (Smatana \& Macák, 2011). There are only a few reports about peculiarities of the crop cultivation under different conditions, for example, of salt stress (Ghavami \& Ramin, 2007). The above-mentioned fact defines the relevance of our study. 


\section{Materials and methods}

The goal of the study was to determine the influence of the cultivation technology elements on seed productivity and oil yield of the milk thistle crops grown on irrigated lands in the South of Ukraine. The studied factors were: A - primary tillage (treatment 1 : shallow tillage at the depth of 14-16 cm; treatment 2: moldboard plowing at the depth of 20-22 cm); B - inter-row spacing (treatment $1: 30 \mathrm{~cm}$, treatment 2 : $45 \mathrm{~cm}$, treatment $3: 60 \mathrm{~cm}$ ); C - timing of sowing (treatment $1:$ 3rd decade of March, treatment 2 : middle of April, treatment $3:$ 3rd decade of April); D - mineral fertilizer application doses (treatment 1 : no fertilizers applied, treatment $2: \mathrm{N}_{45} \mathrm{P}_{45}$, treatment $3: \mathrm{N}_{90} \mathrm{P}_{90}$ ). The field trials were held during the period from 2010 to 2012 at the experimental fields of the Institute of Rice of the National Academy of Agrarian Sciences of Ukraine (latitude $46^{\circ} 08^{\prime} 34^{\prime \prime} \mathrm{N}$, longitude $32^{\circ} 57^{\prime} 15^{\prime \prime} \mathrm{E}$, altitude $8 \mathrm{~m}$ ). The split plot design method of the trials in four replications was used. The sown area of the 4 th rank was $70 \mathrm{~m}^{2}$, and yield registration area was $55 \mathrm{~m}^{2}$

The climate of the zone is moderately continental, and is characterized as dry and warm. Climate conditions form under the influence of the Black Sea. Weather conditions during the period of the trials were unstable and contrasting. Meteorological indices and long-term mean values were obtained from the Kherson Regional Hydro-meteorological Center. As a matter of fact, 2010 was hot and well-supplied with precipitation, 2011 was moderately warm and comparatively dry, while 2012 was the hottest year (Tables 1, 2).

\section{Table 1}

Precipitation amounts during the period of milk thistle growth and development in the field trials (mm)

\begin{tabular}{lcrrrc}
\hline \multirow{2}{*}{ Months } & $\begin{array}{c}\text { Long-term } \\
\text { mean }\end{array}$ & \multicolumn{3}{c}{ Years of the study } & \multirow{2}{*}{$\begin{array}{c}\text { Average for the } \\
\text { studied period } \pm\end{array}$} \\
\cline { 3 - 5 } & values & 2010 & 2011 & 2012 & $\begin{array}{c}\text { standard deviation } \\
\text { stann }\end{array}$ \\
\cline { 3 - 5 } March & 19 & 6.0 & 9.6 & 20.0 & $11.9 \pm 7.1$ \\
April & 24 & 23.8 & 37.8 & 12.5 & $24.7 \pm 0.7$ \\
May & 28 & 33.9 & 58.5 & 144.6 & $79.0 \pm 51.0$ \\
June & 36 & 108.8 & 34.8 & 29.3 & $57.6 \pm 21.6$ \\
July & 29 & 137.6 & 12.8 & 12.2 & $54.2 \pm 25.2$ \\
August & 27 & 0.6 & 3.0 & 54.2 & $19.3 \pm 7.7$ \\
September & 28 & 47.2 & 12.0 & 0.0 & $19.7 \pm 8.3$ \\
Total annual & 307 & 544.0 & 225.3 & 311.8 & $360.4 \pm 53.4$ \\
\hline
\end{tabular}

Table 2

Air temperature during the period

of milk thistle growth and development in the field trials $\left({ }^{\circ} \mathrm{C}\right)$

\begin{tabular}{|c|c|c|c|c|c|}
\hline \multirow{2}{*}{ Months } & \multirow{2}{*}{$\begin{array}{l}\text { Long-term } \\
\text { mean } \\
\text { values }\end{array}$} & \multicolumn{3}{|c|}{ Years of the study } & \multirow{2}{*}{$\begin{array}{l}\text { Average for the } \\
\text { studied period } \pm \\
\text { standard deviation }\end{array}$} \\
\hline & & 2010 & 2011 & 2012 & \\
\hline March & 2.3 & 3.4 & 2.8 & 3.0 & $3.1 \pm 0.8$ \\
\hline April & 10.0 & 10.7 & 10.1 & 11.6 & $10.8 \pm 0.8$ \\
\hline May & 16.0 & 17.6 & 16.5 & 19.8 & $18.0 \pm 2.0$ \\
\hline June & 19.9 & 22.5 & 21.5 & 22.0 & $22.0 \pm 2.1$ \\
\hline July & 21.9 & 24.7 & 24.5 & 26.0 & $25.1 \pm 3.2$ \\
\hline August & 21.3 & 26.1 & 22.6 & 23.5 & $24.1 \pm 2.8$ \\
\hline September & 16.4 & 17.7 & 18.7 & 19.0 & $18.5 \pm 2.1$ \\
\hline Average annual & 9.8 & 11.7 & 11.7 & 11.8 & $11.7 \pm 1.9$ \\
\hline
\end{tabular}

Ground water and irrigation water were analyzed in the certified laboratory of the Kherson Office of the Institute of Land Management of the National Academy of Agrarian Sciences of Ukraine using the standard methods. Calcium and magnesium concentrations were determined by Ethylenediaminetetraacetic acid titration. Sodium concentration was determined on a flame photometer. Chloride concentration was determined by silver nitrate titration. Carbonate and hydro-carbonate concentrations were determined by hydrochloric acid titration. Sulphate concentration was determined by barium chloride titration. Irrigation water used in the trials had a favourable chemical composition and was suitable for irrigation without limitation (Table 3). Ground water lay at the depth of $5 \mathrm{~m}$ and was not involved in the water supply of the cultivated crop. All the analyses were carried out within agrochemical inspections of the fields and water of the Institute of Rice of the National
Academy of Agrarian Sciences of Ukraine. Soil in the trials was represented by the dark-chestnut residual solonetz middle-loamy soil. Power of hydrogen of the soil in the upper layer fluctuated between 7.0 7.5 units. Humus content (determined by the method of Tiurin) in the upper arable layer $(0-30 \mathrm{~cm})$ was $2.25 \%$. Phosphorus (determined by the method of Machygin) and nitrogen content (determined by the method of Tiurin and Kononova) was low, and potassium content (determined by the method of Machygin at the flame photometer) was quite high in the arable soil layer of $0-30 \mathrm{~cm}$ (Table 4).

Table 3

Chemical composition and total dissoluble solids content in the ground water and irrigation water used in the field trials

\begin{tabular}{|c|c|c|}
\hline Qualitative parameters, g/L & Ground water & Irrigation water \\
\hline$\overline{\mathrm{CO}_{3}{ }^{2-}}$ & absent & absent \\
\hline $\mathrm{HCO}_{3}^{-}$ & 0.472 & 0.152 \\
\hline $\mathrm{Cl}^{-}$ & 0.182 & 0.036 \\
\hline $\mathrm{SO}_{4}^{2-}$ & 0.868 & 0.054 \\
\hline $\mathrm{Ca}^{2+}$ & 0.196 & 0.040 \\
\hline $\mathrm{Mg}^{2+}$ & 0.082 & 0.017 \\
\hline $\mathrm{Na}^{+}$ & 0.328 & 0.028 \\
\hline Total dissoluble solids content & 1.969 & 0.252 \\
\hline
\end{tabular}

\section{Table 4}

Humus and nutritive elements content in the arable soil layer of $0-30 \mathrm{~cm}$ in the field trials

\begin{tabular}{cccccc}
\hline $\begin{array}{c}\text { Humus, } \\
\%\end{array}$ & $\begin{array}{c}\text { Nitrogen } \\
\left(\mathrm{NO}_{3}\right), \\
\mathrm{mg} / \mathrm{kg}\end{array}$ & $\begin{array}{c}\text { Nitrogen } \\
\left(\mathrm{NH}_{4}\right), \\
\mathrm{mg} / \mathrm{kg}\end{array}$ & $\begin{array}{c}\text { Total mineral } \\
\text { Nitrofen, } \mathrm{mg} / \mathrm{kg}\end{array}$ & $\begin{array}{c}\text { Mobile } \\
\text { Phosphorus, } \\
\mathrm{mg} / \mathrm{kg}\end{array}$ & $\begin{array}{c}\text { Exchangeable } \\
\text { Potassium, } \\
\mathrm{mg} / \mathrm{kg}\end{array}$ \\
\hline 2.25 & 39.0 & 4.0 & 26.0 & 29.0 & 332.0 \\
\hline
\end{tabular}

The cultivation technology used in the trials was standard for milk thistle growing under irrigated conditions. We cultivated the milk thistle variety Yuhoslava, which has been included on the State Register of Plant Varieties of Ukraine since 2006. The previous crop was winter wheat. After harvesting of the winter wheat, harrowing at the depth of 8-10 cm was conducted. Then mineral fertilizers were applied in accordance with the trials' design doses, and primary tillage was conducted. Field planning and leveling were carried out before frosts in the pre-winter period. Early spring started with dragging at the depth of 4-6 cm. The crop was sown after pre-sowing cultivation in three terms with accordance to the trials' design by the means of SN-16 drill. Aftersowing, rolling was carried out to obtain good push-outs. Pre-sprouting dragging was conducted to clear the fields from weeds. The plots were dragged again at the stage of two leaves of the crop. Inter-row cultivations until the milk thistle leaves had closed up were conducted by means of inter-row cultivator. We maintained the soil moisture in the $0.5-0.7 \mathrm{~m}$ layer at the level of $75-80 \%$ of the field water-holding capacity by means of a frontal sprinkler irrigation machine. Total volume of the irrigation water applied was $1100 \mathrm{~m}^{3} /$ ha in 2010 and 2012, 1650 $\mathrm{m}^{3} / \mathrm{ha}$ in 2011 (or $1283 \mathrm{~m}^{3} / \mathrm{ha}$ in average for the studied period). Seed yields was estimated by the means of "Sampo" self-propelled combine harvester, and then recalculated for the standard seed moisture (12\%) and $100 \%$ of seeds purity. Harvesting of the crop was carried out in the period from the 1st to 2nd decades of September. The oil content in the seeds was determined by using the Klevenger apparatus in the certified laboratory. The yield data was processed by using the multiple analyses of variance (ANOVA) and simple paired correlation analyses within AgroStat MS Excel add-on and LibreOffice Calc 5 software applications. The least significant difference (LSD) between the studied variants was calculated for level of reliability of $95 \%$ ( $\mathrm{P}<0.05)$.

\section{Results}

The results of the study proved that milk thistle productivity significantly depends on the cultivation technology treatments (Table 5). Considerable increase in seed yields was achieved by: increasing the primary tillage depth to 20-22 cm (from 1.12 to 1.17 tha on average); increasing inter-row spacing to 45 and, especially, $60 \mathrm{~cm}$ (from 1.09 to 1.15 and 1.21 tha on average, respectively); the earliest sowing period in the 3rd decade of March, comparatively to delayed sowing (from 
0.92 to 1.33 tha in average); mineral fertilizers' application at a dose of N90P90, comparatively with lower nutritive background (from 0.88 to 1.18 and 1.38 tha in average).

\section{Table 5}

Seed yields of milk thistle in the trials depending on primary tillage depth, inter-row spacing, timing of sowing and mineral fertilizers' application doses at the irrigated lands of the Steppe Zone (t/ha, all the studies were conducted in four replications)

\begin{tabular}{|c|c|c|c|c|c|c|c|}
\hline \multirow[b]{2}{*}{$\begin{array}{l}\text { Primary } \\
\text { tillage } \\
\text { (Factor } \\
\text { A) }\end{array}$} & \multirow[b]{2}{*}{$\begin{array}{l}\text { Inter-row } \\
\text { spacing, } \\
\text { cm } \\
\text { (Factor } \\
\text { B) }\end{array}$} & \multirow[b]{2}{*}{$\begin{array}{l}\text { Terms of } \\
\text { sowing } \\
\text { (Factor C) }\end{array}$} & \multirow[b]{2}{*}{$\begin{array}{c}\text { Mineral } \\
\text { fertilizers } \\
\text { application } \\
\text { doses } \\
\text { (Factor D) }\end{array}$} & \multicolumn{4}{|c|}{ Years of study } \\
\hline & & & & 2010 & 2011 & 2012 & $\begin{array}{l}\text { average } \\
\text { yields } \pm \\
\text { standard } \\
\text { deviation }\end{array}$ \\
\hline \multirow{27}{*}{$\begin{array}{l}\text { Shallow } \\
\text { tillage at } \\
\text { the } \\
\text { depth of } \\
14-16 \\
\mathrm{~cm}\end{array}$} & \multirow{9}{*}{30} & \multirow{3}{*}{$\begin{array}{l}\text { 3rd decade } \\
\text { of March }\end{array}$} & No fertilizers & 0.92 & 1.01 & 0.99 & $0.97 \pm 0.05$ \\
\hline & & & $\mathrm{N}_{45} \mathrm{P}_{45}$ & 1.22 & 1.34 & 1.32 & $1.29 \pm 0.06$ \\
\hline & & & $\mathrm{N}_{90} \mathrm{P}_{90}$ & 1.39 & 1.53 & 1.49 & $1.47 \pm 0.07$ \\
\hline & & \multirow{3}{*}{$\begin{array}{l}\text { Middle } \\
\text { of April }\end{array}$} & No fertilizers & 0.85 & 0.93 & 0.90 & $0.89 \pm 0.04$ \\
\hline & & & $\mathrm{N}_{45} \mathrm{P}_{45}$ & 1.07 & 1.18 & 1.17 & $1.14 \pm 0.06$ \\
\hline & & & $\mathrm{N}_{90} \mathrm{P}_{90}$ & 1.23 & 1.35 & 1.31 & $1.30 \pm 0.06$ \\
\hline & & \multirow{3}{*}{$\begin{array}{l}\text { 3rd decade } \\
\text { of April }\end{array}$} & No fertilizers & 0.52 & 0.67 & 0.64 & $0.61 \pm 0.08$ \\
\hline & & & $\mathrm{N}_{45} \mathrm{P}_{45}$ & 0.79 & 0.87 & 0.83 & $0.83 \pm 0.04$ \\
\hline & & & $\mathrm{N}_{90} \mathrm{P}_{90}$ & 1.01 & 1.18 & 1.13 & $1.11 \pm 0.09$ \\
\hline & \multirow{9}{*}{45} & \multirow{3}{*}{$\begin{array}{l}\text { 3rd decade } \\
\text { of March }\end{array}$} & No fertilizers & 1.00 & 1.10 & 1.05 & $1.05 \pm 0.05$ \\
\hline & & & $\mathrm{N}_{45} \mathrm{P}_{45}$ & 1.28 & 1.41 & 1.36 & $1.35 \pm 0.07$ \\
\hline & & & $\mathrm{N}_{90} \mathrm{P}_{90}$ & 1.46 & 1.60 & 1.55 & $1.54 \pm 0.07$ \\
\hline & & \multirow{3}{*}{$\begin{array}{l}\text { Middle } \\
\text { of April }\end{array}$} & No fertilizers & 0.85 & 0.96 & 0.91 & $0.91 \pm 0.06$ \\
\hline & & & $\mathrm{N}_{45} \mathrm{P}_{45}$ & 1.16 & 1.27 & 1.22 & $1.21 \pm 0.06$ \\
\hline & & & $\mathrm{N}_{90} \mathrm{P}_{90}$ & 1.35 & 1.40 & 1.39 & $1.38 \pm 0.03$ \\
\hline & & \multirow{3}{*}{$\begin{array}{l}\text { 3rd decade } \\
\text { of April }\end{array}$} & No fertilizers & 0.61 & 0.68 & 0.66 & $0.65 \pm 0.04$ \\
\hline & & & $\mathrm{N}_{45} \mathrm{P}_{45}$ & 0.83 & 0.91 & 0.89 & $0.87 \pm 0.04$ \\
\hline & & & $\mathrm{N}_{90} \mathrm{P}_{90}$ & 1.08 & 1.20 & 1.16 & $1.15 \pm 0.06$ \\
\hline & \multirow{9}{*}{60} & \multirow{3}{*}{$\begin{array}{l}\text { 3rd decade } \\
\text { of March }\end{array}$} & No fertilizers & 1.02 & 1.14 & 1.10 & $1.09 \pm 0.06$ \\
\hline & & & $\mathrm{N}_{45} \mathrm{P}_{45}$ & 1.33 & 1.47 & 1.42 & $1.41 \pm 0.07$ \\
\hline & & & $\mathrm{N}_{90} \mathrm{P}_{90}$ & 1.54 & 1.65 & 1.61 & $1.60 \pm 0.06$ \\
\hline & & \multirow{3}{*}{$\begin{array}{l}\text { Middle } \\
\text { of April }\end{array}$} & No fertilizers & 0.89 & 0.96 & 0.94 & $0.93 \pm 0.04$ \\
\hline & & & $\mathrm{N}_{45} \mathrm{P}_{45}$ & 1.22 & 1.36 & 1.31 & $1.30 \pm 0.07$ \\
\hline & & & $\mathrm{N}_{90} \mathrm{P}_{90}$ & 1.41 & 1.51 & 1.45 & $1.46 \pm 0.05$ \\
\hline & & & No fertilizers & 0.64 & 0.69 & 0.67 & $0.67 \pm 0.03$ \\
\hline & & ora a anil & $\mathrm{N}_{45} \mathrm{P}_{45}$ & 0.92 & 1.01 & 0.97 & $0.97 \pm 0.05$ \\
\hline & & & $\mathrm{N}_{90} \mathrm{P}_{90}$ & 1.13 & 1.29 & 1.23 & $1.21 \pm 0.08$ \\
\hline & & & No fertilizers & 0.94 & 1.04 & 1.01 & \pm 0.05 \\
\hline & & & $\mathrm{N}_{45} \mathrm{P}_{45}$ & 1.26 & 1.39 & 1.35 & $1.33 \pm 0.07$ \\
\hline & & & $\mathrm{N}_{90} \mathrm{P}_{90}$ & 1.44 & 1.58 & 1.54 & $1.52 \pm 0.07$ \\
\hline & & & No fertilizers & 0.88 & 0.98 & 0.96 & $0.94 \pm 0.05$ \\
\hline & 30 & ivila & $\mathrm{N}_{45} \mathrm{P}_{45}$ & 1.14 & 1.24 & 1.21 & $1.19 \pm 0.05$ \\
\hline & & & $\mathrm{N}_{90} \mathrm{P}_{90}$ & 1.30 & 1.40 & 1.34 & $1.35 \pm 0.05$ \\
\hline & & & No fertilizers & 0.60 & 0.69 & 0.65 & $0.65 \pm 0.05$ \\
\hline & & Sra deca & $\mathrm{N}_{45} \mathrm{P}_{45}$ & 0.85 & 0.97 & 0.92 & $0.91 \pm 0.06$ \\
\hline & & & $\mathrm{N}_{90} \mathrm{P}_{90}$ & 1.06 & 1.22 & 1.18 & $1.15 \pm 0.08$ \\
\hline & & & No fertilizers & 1.02 & 1.12 & 1.09 & $1.07 \pm 0.05$ \\
\hline & & 31 & $\mathrm{~N}_{45} \mathrm{P}_{45}$ & 1.32 & 1.49 & 1.40 & $1.40 \pm 0.09$ \\
\hline & & & $\mathrm{N}_{90} \mathrm{P}_{90}$ & 1.51 & 1.62 & 1.58 & $1.57 \pm 0.06$ \\
\hline & & & No fertilizers & 0.87 & 0.99 & 0.93 & $0.93 \pm 0.06$ \\
\hline & 45 & Mide & $\mathrm{N}_{45} \mathrm{P}_{45}$ & 1.20 & 1.32 & 1.28 & $1.26 \pm 0.06$ \\
\hline & & & $\mathrm{N}_{90} \mathrm{P}_{90}$ & 1.39 & 1.43 & 1.41 & $1.41 \pm 0.02$ \\
\hline & & & No fertilizers & 0.66 & 0.72 & 0.71 & $0.70 \pm 0.03$ \\
\hline & & & $\mathrm{N}_{45} \mathrm{P}_{45}$ & 0.91 & 1.04 & 0.95 & $0.97 \pm 0.07$ \\
\hline & & & $\mathrm{N}_{90} \mathrm{P}_{90}$ & 1.14 & 1.27 & 1.22 & $1.21 \pm 0.07$ \\
\hline & & & No fertilizers & 1.06 & 1.16 & 1.13 & $1.12 \pm 0.05$ \\
\hline & & siu deca & $\mathrm{N}_{45} \mathrm{P}_{45}$ & 1.40 & 1.55 & 1.48 & $1.48 \pm 0.08$ \\
\hline & & & & 1.61 & 1.73 & 1.65 & $1.66 \pm 0.06$ \\
\hline & & & No fertilizers & 0.94 & 1.04 & 1.01 & $0.99 \pm 0.05$ \\
\hline & 60 & vilaale & $\mathrm{N}_{45} \mathrm{P}_{45}$ & 1.29 & 1.42 & 1.34 & $1.35 \pm 0.07$ \\
\hline & & & & 1.42 & 1.55 & 1.49 & $1.49 \pm 0.07$ \\
\hline & & & No fertilizers & 0.69 & 0.77 & 0.75 & $0.74 \pm 0.04$ \\
\hline & & & $\mathrm{N}_{45} \mathrm{P}_{45}$ & 0.97 & 1.10 & 1.05 & $1.04 \pm 0.06$ \\
\hline & & & & 1.21 & 1.33 & 1.28 & $1.28 \pm 0.07$ \\
\hline
\end{tabular}

We consider, that moldboard plowing at the depth of $20-22 \mathrm{~cm}$ creates more favorable conditions for good development of the root system of the crop. At the same time, wider inter-row spacing provides better facilities for growth and development of the overground vegetative mass of milk thistle plants, which can be explained by better nutritive, air and light regimes in the crops, owing to lower density of plants per unit area. Delayed sowing subjects the crops to unfavourable weather conditions for vegetation, thus it leads to productivity decrease. And the more mineral fertilizers we used, the higher the seeds yields were, because of considerable improvement of the crops nutrition. The maximum input in seed yields was made by the mineral fertilizers at a dose of $\mathrm{N}_{90} \mathrm{P}_{90}$ : seed yields increased by 1.57 times comparatively to non-fertilized treatment. The results of the study established an opportunity of considerably raising the milk thistle seed yields through use of rational cultivation technology, for example, in our case up to 1.05 t/ha (from 0.61 to 1.66 tha). Results of ANOVA milk thistle seed yields data processing are represented in Table 7.

\section{Table 6}

Average seed yields of milk thistle in the trials depending on primary tillage depth, inter-row spacing, timing of sowing and mineral fertilizers' application doses at the irrigated lands of the Steppe Zone (t/ha)

\begin{tabular}{clc}
\hline $\begin{array}{c}\text { Factors } \\
\text { signatures }\end{array}$ & \multicolumn{1}{c}{ Treatments } & $\begin{array}{c}\text { Seed yields } \\
\text { of milk thistle }\end{array}$ \\
\hline \multirow{2}{*}{ A } & Shallow tillage at the depth of $14-16 \mathrm{~cm}$ & 1.12 \\
& Moldboard plowing at the depth of $20-22 \mathrm{~cm}$ & 1.17 \\
\hline \multirow{2}{*}{$\mathrm{B}$} & Inter-row spacing of $30 \mathrm{~cm}$ & 1.09 \\
& Inter-row spacing of $45 \mathrm{~cm}$ & 1.15 \\
& Inter-row spacing of $60 \mathrm{~cm}$ & 1.21 \\
\hline \multirow{2}{*}{$\mathrm{C}$} & Sowing in the 3rd decade of March & 1.33 \\
& Sowing in the middle of April & 1.19 \\
& Sowing in the 3rd decade of April & 0.92 \\
\hline \multirow{2}{*}{$\mathrm{D}$} & No mineral fertilizers applied & 0.88 \\
& Mineral fertilizers dose of $\mathrm{N}_{45} \mathrm{P}_{45}$ & 1.18 \\
& Mineral fertilizers dose of $\mathrm{N}_{90} \mathrm{P}_{90}$ & 1.38 \\
\hline
\end{tabular}

Notes. For the average milk thistle seed yields LSD at $\mathrm{P}<0.05$ for the major effects of the studied factors (tha): $\mathrm{A}=0.034 ; \mathrm{B}=0.008 ; \mathrm{C}=0.005 ; \mathrm{D}=0.007$. LSD at $\mathrm{P}<0.05$ for the partial effects of the studied factors (tha): $\mathrm{A}=0.177 ; \mathrm{B}=$ $0.033 ; \mathrm{C}=0.023 ; \mathrm{D}=0.030$. All the studied factors had significant influence on the milk thistle seeds yield.

The above-mentioned statements are true for the milk thistle oil yields too (Table 7). The highest oil yield of $489 \mathrm{~kg} / \mathrm{ha}$ on average was obtained under the moldboard plowing at the depth of 20-22 cm, interrow spacing $60 \mathrm{~cm}$, sowing in the 3rd decade of March and applying mineral fertilizers at the dose of $\mathrm{N}_{90} \mathrm{P}_{90}$. Increase of the primary tillage depth raised oil yields up to $4.66 \%$; cultivation under wider inter-row spacing increased oil yields up to $5.11 \%$ and $5.47 \%$; delayed sowing resulted in oil yields decrease down to $11.73 \%$ and $28.20 \%$. The maximum input in oil yields was provided by the mineral fertilizers that increased the latter up to $37.55 \%$ and $20.47 \%$. A strong direct dependence of the milk thistle seed yields and oil yields was determined: correlation coefficient between this features was 0.98 , coefficient of determination -0.96 .

\section{Discussion}

For the first time we established relations between milk thistle productivity and cultivation technology elements, viz., primary tillage depth, inter-row spacing, timing of sowing, mineral fertilizers' application doses, on irrigated lands in the steppe zone. Connecting our results to those of other similar studies, we found a lot of common and also quite different features and points. One of the divergences is that the results of our study prove a considerable difference in milk thistle yields depending on timing of sowing. But some studies do not mention any significant influence of sowing timing on milk thistle productivity (Andrzejewska et al., 2011). On the other hand, research works of another team of authors proved that a delayed sowing date obviously resulted in a significant reduction in fruit per inflorescence (Rahimi \& Kamali, 2012).The above-mentioned discrepancy between the studies can be referred to difference in soil-climate conditions of the studies.

The common points of almost all the scientific studies is the significant productivity increase of the milk thistle crops, achieved due to use of mineral and organic fertilizers in proper doses and preparative 
forms, especially, Nitrogen (Wierzbowska et al., 2012), manures (Haban et al., 2009; Asfar et al., 2014; Haban et al., 2015) and natural stimulants (Saad-Allah et al., 2017). There is a study proving the high efficiency of foliage fertilizers (Stancheva et al., 2010).

\section{Table 7}

Milk thistle oil yields in the trials depending on primary tillage depth, inter-row spacing, timing of sowing and mineral fertilizers application doses at the irrigated lands of the Steppe Zone

( $\mathrm{kg} / \mathrm{ha}$, all the studies were conducted in four replications)

\begin{tabular}{|c|c|c|c|c|c|c|c|}
\hline \multirow[b]{2}{*}{$\begin{array}{c}\text { Primary } \\
\text { tillage } \\
\text { (Factor } \\
\text { A) }\end{array}$} & \multirow[b]{2}{*}{$\begin{array}{l}\text { Inter-row } \\
\text { spacing, } \\
\text { cm } \\
\text { (Factor } \\
\text { B) }\end{array}$} & \multirow[b]{2}{*}{$\begin{array}{l}\text { Terms of } \\
\text { sowing } \\
\text { (Factor C) }\end{array}$} & \multirow[b]{2}{*}{$\begin{array}{c}\text { Mineral } \\
\text { fertilizers } \\
\text { application } \\
\text { doses } \\
\text { (Factor D) }\end{array}$} & \multicolumn{4}{|c|}{ Years of study } \\
\hline & & & & 2010 & 2011 & 2012 & $\begin{array}{c}\text { average } \\
\text { yields } \pm \\
\text { standard } \\
\text { deviation }\end{array}$ \\
\hline \multirow{27}{*}{$\begin{array}{l}\text { Shallo } \\
\text { w } \\
\text { tillage } \\
\text { at the } \\
\text { depth } \\
\text { of } 14- \\
16 \mathrm{~cm}\end{array}$} & \multirow{9}{*}{30} & \multirow{3}{*}{$\begin{array}{l}\text { 3rd decade } \\
\text { of March }\end{array}$} & No fertilizers & 256 & 281 & 274 & $270 \pm 12.9$ \\
\hline & & & $\mathrm{N}_{45} \mathrm{P}_{45}$ & 347 & 382 & 376 & $368 \pm 18.7$ \\
\hline & & & $\mathrm{N}_{90} \mathrm{P}_{90}$ & 410 & 450 & 438 & $433 \pm 20.5$ \\
\hline & & \multirow{3}{*}{$\begin{array}{l}\text { Middle } \\
\text { of April }\end{array}$} & No fertilizers & 235 & 259 & 251 & $248 \pm 12.2$ \\
\hline & & & $\mathrm{N}_{45} \mathrm{P}_{45}$ & 306 & 337 & 333 & $325 \pm 16.9$ \\
\hline & & & $\mathrm{N}_{90} \mathrm{P}_{90}$ & 362 & 398 & 384 & $381 \pm 18.1$ \\
\hline & & \multirow{3}{*}{$\begin{array}{l}\text { 3rd decade } \\
\text { of April }\end{array}$} & No fertilizers & 143 & 187 & 177 & $169 \pm 23.1$ \\
\hline & & & $\mathrm{N}_{45} \mathrm{P}_{45}$ & 224 & 247 & 237 & $236 \pm 11.5$ \\
\hline & & & $\mathrm{N}_{90} \mathrm{P}_{90}$ & 298 & 346 & 332 & $325 \pm 24.7$ \\
\hline & \multirow{9}{*}{45} & \multirow{3}{*}{$\begin{array}{l}\text { 3rd decade } \\
\text { of March }\end{array}$} & No fertilizers & 277 & 305 & 293 & $292 \pm 14.0$ \\
\hline & & & $\mathrm{N}_{45} \mathrm{P}_{45}$ & 365 & 402 & 388 & $385 \pm 18.7$ \\
\hline & & & $\mathrm{N}_{90} \mathrm{P}_{90}$ & 428 & 470 & 456 & $451 \pm 21.4$ \\
\hline & & \multirow{3}{*}{$\begin{array}{l}\text { Middle } \\
\text { of April }\end{array}$} & No fertilizers & 237 & 266 & 252 & $252 \pm 14.5$ \\
\hline & & & $\mathrm{N}_{45} \mathrm{P}_{45}$ & 329 & 362 & 346 & $346 \pm 16.5$ \\
\hline & & & $\mathrm{N}_{90} \mathrm{P}_{90}$ & 396 & 412 & 410 & $406 \pm 8.7$ \\
\hline & & \multirow{3}{*}{$\begin{array}{l}\text { 3rd decade } \\
\text { of April }\end{array}$} & No fertilizers & 170 & 190 & 183 & $181 \pm 10.1$ \\
\hline & & & $\mathrm{N}_{45} \mathrm{P}_{45}$ & 236 & 260 & 252 & $249 \pm 12.2$ \\
\hline & & & $\mathrm{N}_{90} \mathrm{P}_{90}$ & 319 & 354 & 342 & $338 \pm 17.8$ \\
\hline & \multirow{9}{*}{60} & \multirow{3}{*}{$\begin{array}{l}\text { 3rd decade } \\
\text { of March }\end{array}$} & No fertilizers & 285 & 317 & 306 & $303 \pm 16.3$ \\
\hline & & & $\mathrm{N}_{45} \mathrm{P}_{45}$ & 380 & 418 & 405 & $401 \pm 19.3$ \\
\hline & & & $\mathrm{N}_{90} \mathrm{P}_{90}$ & 451 & 484 & 472 & $469 \pm 16.7$ \\
\hline & & \multirow{3}{*}{$\begin{array}{l}\text { Middle } \\
\text { of April }\end{array}$} & No fertilizers & 248 & 266 & 260 & $258 \pm 9.2$ \\
\hline & & & $\mathrm{N}_{45} \mathrm{P}_{45}$ & 348 & 388 & 373 & $370 \pm 20.2$ \\
\hline & & & $\mathrm{N}_{90} \mathrm{P}_{90}$ & 415 & 443 & 427 & $428 \pm 14.0$ \\
\hline & & & No fertilizers & 177 & 192 & 187 & $185 \pm 7.6$ \\
\hline & & 3rd decade & $\mathrm{N}_{45} \mathrm{P}_{45}$ & 262 & 288 & 278 & $276 \pm 13.1$ \\
\hline & & & $\mathrm{N}_{90} \mathrm{P}_{90}$ & 331 & 380 & 361 & $357 \pm 24.7$ \\
\hline & & & No fertilizers & 262 & 288 & 281 & $277 \pm 13.5$ \\
\hline & & & $\mathrm{N}_{45} \mathrm{P}_{45}$ & 359 & 395 & 386 & $380 \pm 18.7$ \\
\hline & & & $\mathrm{N}_{90} \mathrm{P}_{90}$ & 422 & 464 & 452 & $446 \pm 21.6$ \\
\hline & & & No fertilizers & 245 & 273 & 266 & $261 \pm 14.6$ \\
\hline & 30 & & $\mathrm{~N}_{45} \mathrm{P}_{45}$ & 323 & 352 & 345 & $340 \pm 15.1$ \\
\hline & & & $\mathrm{N}_{90} \mathrm{P}_{90}$ & 382 & 410 & 395 & $396 \pm 14.0$ \\
\hline & & & No fertilizers & 166 & 193 & 179 & $179 \pm 13.5$ \\
\hline & & 3rd decade & $\mathrm{N}_{45} \mathrm{P}_{45}$ & 241 & 276 & 261 & $259 \pm 17.6$ \\
\hline & & & $\mathrm{N}_{90} \mathrm{P}_{90}$ & 312 & 357 & 347 & $339 \pm 23.6$ \\
\hline & & & No fertilizers & 283 & 311 & 302 & $299 \pm 14.3$ \\
\hline Moldb & & $3 r d d$ & $\mathrm{~N}_{45} \mathrm{P}_{45}$ & 376 & 424 & 400 & $400 \pm 24.0$ \\
\hline & & & $\mathrm{N}_{90} \mathrm{P}_{90}$ & 444 & 477 & 464 & $462 \pm 16.6$ \\
\hline plowin & & & No fertilizers & 243 & 275 & 257 & $258 \pm 16.0$ \\
\hline$g$ at the & 45 & & $\mathrm{~N}_{45} \mathrm{P}_{45}$ & 341 & 375 & 363 & $360 \pm 17.2$ \\
\hline depth & & & $\mathrm{N}_{90} \mathrm{P}_{90}$ & 410 & 421 & 414 & $415 \pm 5.6$ \\
\hline of $20-$ & & & No fertilizers & 182 & 201 & 197 & $193 \pm 10.0$ \\
\hline & & & $\mathrm{N}_{45} \mathrm{P}_{45}$ & 260 & 295 & 271 & $275 \pm 17.9$ \\
\hline & & & $\mathrm{N}_{90} \mathrm{P}_{90}$ & 336 & 372 & 359 & $356 \pm 18.2$ \\
\hline & & & No fertilizers & 294 & 323 & 314 & $310 \pm 14.8$ \\
\hline & & & $\mathrm{N}_{45} \mathrm{P}_{45}$ & 400 & 442 & 422 & $421 \pm 21.0$ \\
\hline & & & $\mathrm{N}_{90} \mathrm{P}_{90}$ & 473 & 509 & 485 & $489 \pm 18.3$ \\
\hline & & & No fertilizers & 262 & 288 & 279 & $276 \pm 13.2$ \\
\hline & 60 & Middle & $\mathrm{N}_{45} \mathrm{P}_{45}$ & 366 & 406 & 381 & $384 \pm 20.2$ \\
\hline & & & $\mathrm{N}_{90} \mathrm{P}_{90}$ & 418 & 455 & 438 & $437 \pm 18.5$ \\
\hline & & & No fertilizers & 192 & 214 & 209 & $205 \pm 11.5$ \\
\hline & & 3rd decade & $\mathrm{N}_{45} \mathrm{P}_{45}$ & 278 & 312 & 298 & $296 \pm 17.1$ \\
\hline & & & $\mathrm{N}_{90} \mathrm{P}_{90}$ & 356 & 392 & 377 & $375 \pm 18.1$ \\
\hline
\end{tabular}

Application of fertilizers significantly improved roots growth and development, which resulted in higher crop productivity (Angelopoulou et al., 2014). Some of the studies also report an earlier start of the flowering stage and generally stronger and healthier plants due to treatment with fertilizers (Nasrabadi et al., 2014). It was also established by some scientists, that milk thistle oil yields are higher under treatments with fertilizers (Asfar et al., 2014). It was proved, that for obtaining high yields of milk thistle in dry zones with little rainfall, the crop should be cultivated under irrigated conditions (Karkanis et al., 2011; Asfar et al., 2015). In spite of the fact that the milk thistle needs proper soil moisture for better productivity, the crop can be successfully cultivated under the moderate deficit irrigation (Keshavarz Afshar et al., 2015). Drought stress can even increase oil quality of milk thistle (Malekzadeh et al., 2011). We should point out that we were the first to pay particular attention to the reaction of milk thistle on the inter-row spacing and primary tillage depth in irrigated conditions of the steppe zone. But it should be mentioned here, that some scientific studies report contradictory data to our results, that is to say that higher milk thistle seed yields were obtained under the narrow inter-row spacing $(25 \mathrm{~cm})$, while we obtained the maximum yields at the widest inter-row spacing treatments (60 cm). It has also been stated, that wider inter-row spacing is considered as worse treatment for seed yields, but not for the oil content in the seeds (Omer et al., 1993). Concerning the primary tillage depth, our results are in tune with some other studies reporting the maximum milk thistle seed yields were obtained under the plowing at a depth of 25$27 \mathrm{~cm}$, comparative to the shallow tillage on 18-20 cm (Nikolaychenko et al., 2018). Results of ANOVA data processing of milk thistle oil yields are represented in Table 8.

\section{Table 8}

Average milk thistle oil yields in the trials depending on primary tillage depth, inter-row spacing, timing of sowing and mineral fertilizers application doses at the irrigated lands of the Steppe Zone ( $\mathrm{kg} / \mathrm{ha})$

\begin{tabular}{clc}
\hline $\begin{array}{c}\text { Factors } \\
\text { signatures }\end{array}$ & \multicolumn{1}{c}{ Treatments } & $\begin{array}{c}\text { Milk thistle oil } \\
\text { yields }\end{array}$ \\
\hline \multirow{2}{*}{ A } & Shallow tillage at the depth of $14-16 \mathrm{~cm}$ & 322 \\
& Moldboard plowing at the depth of $20-22 \mathrm{~cm}$ & 337 \\
\hline \multirow{2}{*}{$\mathrm{B}$} & Inter-row spacing of $30 \mathrm{~cm}$ & 313 \\
& Inter-row spacing of $45 \mathrm{~cm}$ & 329 \\
& Inter-row spacing of $60 \mathrm{~cm}$ & 347 \\
\hline \multirow{2}{*}{$\mathrm{C}$} & Sowing in the 3rd decade of March & 381 \\
& Sowing in the middle of April & 341 \\
& Sowing in the 3rd decade of April & 266 \\
\hline \multirow{2}{*}{$\mathrm{D}$} & No mineral fertilizers applied & 245 \\
& Mineral fertilizers dose of $\mathrm{N}_{45} \mathrm{P}_{45}$ & 337 \\
& Mineral fertilizers dose of $\mathrm{N}_{90} \mathrm{P}_{90}$ & 406 \\
\hline
\end{tabular}

Notes. For the average milk thistle oil yields LSD at $\mathrm{P}<0.05$ for the major effects of the studied factors (kg/ha): $\mathrm{A}=9.2 ; \mathrm{B}=2.3 ; \mathrm{C}=1.6 ; \mathrm{D}=2.0$. $\mathrm{LSD}$ at $\mathrm{P}<0.05$ for the partial effects of the studied factors $(\mathrm{kg} / \mathrm{ha})$ : $\mathrm{A}=47.8 ; \mathrm{B}=9.8 ; \mathrm{C}=6.7 ; \mathrm{D}=$ 8.5. All the studied factors had significant influence on the milk thistle oil yield.

A strong point of our study, compared with others, is the multi-factorial design of the trials, which allowed us to estimate crop productivity under the influence of interacting cultivation technology elements. Understanding the presence of some limitations in the current study, we are going to continue scientific research in the field of milk thistle cultivation technology. We hope that our study will give a powerful incentive to production of milk thistle, as a highly valuable medicinal plant.

\section{Conclusions}

Milk thistle productivity was considerably affected by all the studied cultivation technology elements, which has been proved by the ANOVA results. The highest average seed yield (1.66 t/ha) and oil yield (489 kg/ha) was obtained under moldboard plowing at the depth of 20$22 \mathrm{~cm}$, mineral fertilizer application at a dose of $\mathrm{N}_{90} \mathrm{P}_{90}$, sowing in the third decade of March with inter-row spacing of $60 \mathrm{~cm}$. The maximum input in raising the crop productivity was made by fertilization. We recommend the cultivation of milk thistle by the above-mentioned agrotechnical complex on irrigated lands in the South of Ukraine.

\section{References}

Afshar, R. K., Chaichi, M. R., Alipour, A., Jovini, M. A., Dashtaki, M., \& Hashemi, M. (2015). Potential of milk thistle for biomass production in semiarid regions. Crop Science, 55(3), 1295-1301. 
Afshar, R. K., Chaichi, M. R., Assareh, M. H., Hashemi, M., \& Liaghat, A. (2014). Interactive effect of deficit irrigation and soil organic amendments on seed yield and flavonolignan production of milk thistle (Silybum marianum L. Gaertn.). Industrial Crops and Products, 58, 166-172.

Albassam, A. A., Frye, R. F., \& Markowitz, J. S. (2017). The effect of milk thistle (Silybum marianum) and its main flavonolignans on CYP2C8 enzyme activity in human liver microsomes. Chemico-Biological Interactions, 271, 24-29.

Andrzejewska, J., Sadowska, K., \& Mielcarek, S. (2011). Effect of sowing date and rate on the yield and flavonolignan content of the fruits of milk thistle (Silybum marianum L. Gaertn.) grown on light soil in a moderate climate. Industrial Crops and Products, 33(2), 462-468.

Angelopoulou, F., Kakabouki, I., Papastylianou, P., Papatheohari, Y., Konstantas, A., Karkanis, A., Travlos, I., \& Bilalis, D. J. (2014). Effect of organic fertilization on growth and development of the root system of two medicinal plants, oregano (Origanum vulgare L.) and milk thistle (Silybum marianum L. Gaertn.). Bulletin UASVM Horticulture, 71, 2.

Barnes, J., Anderson, L. A., \& Phillipson, J. D. (2003). Herbal medicines: A guide for healthcare professionals. Pharmaceutical Press, London.

Carrier, D. J., Crowe, T., Sokhansanj, S., Wahab, J., \& Barl, B. (2002). Milk thistle, Silybum marianum L. Gaertn., flower head development and associated marker compound profile. Journal of Herbs, Spices and Medical Plants, 10, 65-74.

Chiavari, G., Galletti, G. C., Marotti, M., \& Piccaglia, R. (1991). Silymarin content of different Silybum marianum L. Gaertn. cultivars. Herba Hungarica, 12, 23-27.

Flora, K., Hahn, M., Rosen, H., \& Benner, K. (1998). Milk thistle (Silybum marianum (L.) Gaertn.) for the therapy and liver disease. American Journal of Gastroenterology, 93(2), 139-143.

Ghavami, N., \& Ramin, A. A. (2007). Salinity and temperature effects on seed germination of milk thistle. Communications in Soil Science and Plant Analysis, 38, 2681-2691.

Habán, M., Luščáková, D., Habánová, M., Macák, M., \& Kobidová, R. (2015). Yield potential of milk thistle production in south western Slovakia. Acta Fytotechnica et Zootechnica, 18(4), 79-82.

Haban, M., Otepka, P., Kobida, L., \& Habanova, M. (2009). Production and quality of milk thistle (Silybum marianum [L.] Gaertn.) cultivated in cultural conditions of warm agri-climatic macroregion. Horticultural Science, 36(2), 69-74.

Karkanis, A., Bilalis, D., \& Efthimiadou, A. (2011). Cultivation of milk thistle (Silybum marianum L. Gaertn.), a medicinal weed. Industrial Crops and Products, 34(1), 825-830.

Keshavarz Afshar, R., Chaichi, M. R., Rezaei, K., Asareh, M. H., Karimi, M., \& Hashemi, M. (2015). Irrigation regime and organic fertilizers influence on oil content and fatty acid composition of milk thistle seeds. Agronomy Journal, 107(1), 187-194.

Khan, M. A., Blackshaw, R. E., \& Marwat, K. B. (2009). Biology of milk thistle (Silybum marianum) and the management options for growers in northWestern Pakistan. Weed Biology and Management, 9(2), 99-105.

Lange, D. (2002). Medicinal and aromatic plants: Trade, production, and management of botanical resources. XXVI International Horticultural Congress: The Future for Medicinal and Aromatic Plants, 629, 177-197.

Lucini, L., Kane, D., Pellizzoni, M., Ferrari, A., Trevisi, E., Ruzickova, G., \& Arslan, D. (2016). Phenolic profile and in vitro antioxidant power of different milk thistle [Silybum marianum (L.) Gaertn.] cultivars. Industrial Crops and Products, 83, 11-16.
Malekzadeh, M., Mirmazloum, S. I., Mortazavi, S. N., Panahi, M., \& Angorani, H. R. (2011). Physicochemical properties and oil constituents of milk thistle (Silybum marianum Gaertn. cv. Budakalszi) under drought stress. Joumal of Medicinal Plants Research, 5(13), 2886-2889.

Morazzoni, P., \& Bombardelli, E. (1995). Silybum marianum (Carduus marianus). Fitoterapia, 66, 3-42.

Nasrabadi, S. E., Ghorbani, R., Moghaddam, P. R., \& Mahallati, M. N. (2014). Phenological response of milk thistle (Silybum marianum [L.] Gaertn.) to different nutrition systems. Journal of Applied Research on Medicinal and Aromatic Plants, 1(4), 148-151.

Nikolaychenko, N. V., Eskov, I. D., Druzhkin, A. F., Kishnikatina, A. N., Strizhkov, N. I., \& Shyurova, N. A. (2018). Yield, oil content and biochemical composition of seeds of milk thistle, depending on the methods of soil cultivation in the Volga region steppe zone. Journal of Pharmaceutical Sciences and Research, 10(1), 223-227.

Omer, E. A., Refaat, A. M., Ahmed, S. S., Kamel, A., \& Hammouda, F. M. (1993). Effect of spacing and fertilization on the yield and active constituents of milk thistle, Silybum marianum. Journal of Herbs, Spices and Medicinal Plants, 1(4), 17-23.

Post-White, J., Ladas, E. J., \& Kelly, K. M. (2007). Advances in the use of milk thistle (Silybum marianum). Integrative Cancer Therapies, 6(2), 104-109.

Rahimi, A., \& Kamali, M. (2012). Different planting date and fertilizing system effects on the seed yield, essential oil and nutrition uptake of milk thistle (Silybum marianum (L.) Gaertn.). Advances in Environmental Biology, 6(5), 1789-1796.

Ross, S. M. (2008). Milk thistle (Silybum marianum): An ancient botanical medicine for modern times. Holistic Nursing Practice, 22(5), 299-300.

Saad-Allah, K. M., Fetouh, M. I., \& Elhaak, M. A. (2017). Induction of milk thistle (Silybum marianum L. Gaertn) growth and phytochemicals production by natural stimulants. Journal of Applied Research on Medicinal and Aromatic Plants, 6, 101-110.

Saki, K., Eftekhari, Z., Jelodari, M., Shahsavari, S., Moradifar, M., \& Bahmani, M. (2015). Therapeutic effects and pharmaceutical products manufactured from milk thistle (Silybum marianum) in Iran. Advanced Herbal Medicine, 1(2), 1-3.

Seeff, L. B., Lindsay, K. L., Bacon, B. R., Kresina, T. F., \& Hoofnagle, J. H. (2001). Complementary and altemative medicine in chronic liver disease. Hepatology, 34(3), 595-603.

Shamsi, K. (2009). Effect of planting date and density on the yield and yield components of milk thistle (Silybum marianum L.). Journal of Applied Biosciences, 16, 862-863.

Siegel, A. B., \& Stebbing, J. (2013). Milk thistle: Early seeds of potential. The Lancet Oncology, 14(10), 929.

Smatana, J., \& Macák, M. (2011). Analysis of cropping patterns of medicinal and spices plants growing on prime arable land. Acta Fytotechnica et Zootechnica, 14(2), 37-40.

Stancheva, I., Georgiev, G., Geneva, M., Ivanova, A., Dolezal, M., \& Tumova, L. (2010). Influence of foliar fertilization and growth regulator on milk thistle seed yield and quality. Journal of Plant Nutrition, 33(6), 818-830.

Tamayo, C., \& Diamond, S. (2007). Review of clinical trials evaluating safety and efficacy of milk thistle (Silybum marianum [L.] Gaertn.). Integrative Cancer Therapies, 6(2), 146-157.

Wierzbowska, J., Bowszys, T., \& Sternik, P. (2012). Effect of a nitrogen fertilization rate on the yield and yield structure of milk thistle (Silybum marianum (L.) Gaertn.). Ecological Chemistry and Engineering A, 19(3), 295-300. 